Research Paper

\title{
Mycological contamination in dental unit waterlines in Istanbul, Turkey
}

\author{
Duygu Göksay Kadaifciler ${ }^{1}$, Suzan Ökten ${ }^{2}$, Burhan Sen $^{2}$ \\ ${ }^{1}$ Department of Biology, Faculty of Science, Istanbul University, Vezneciler, Istanbul, Turkey. \\ ${ }^{2}$ Department of Biology, Faculty of Science, Trakya University, Edirne, Turkey.
}

Submitted: January 31, 2012; Approved: November 13, 2012.

\begin{abstract}
Studies on dental units (DUs) are conducted either for the prevention or the reduction of the density of bacterial contamination in dental unit waterlines (DUWLs). However, the existence of fungi in the these systems requires more attention. During dental treatment, direct contact with water contaminated with fungi such as Candida, Aspergillus, or inhalation of aerosols from high-speed drill may cause various respiratory infections, such as asthma, allergies, and wounds on mucose membranes, especially on immunocompromised patients and dentists. The aims of this study are to investigate the number and colonization of fungi in DUWLs in the city of Istanbul, Turkey. Water samples were collected from air-water syringes, high-speed drills, and inlet waters from 41 DUs. The aerobic mesophilic fungi count in high- speed drills was higher than inlet waters and air-water syringes. Non-sporulating fungi were found in 7 DUs. The isolated fungi were identified as Penicillium waksmanii, Cladosporium spp., Penicillium spp., Candida famata, Cryptococcus laurentii, Candida guilliermondii, Penicillium verrucosum, Aspergillus pseudoglaucus, Penicillium decumbens, and Acremonium $s p$. Some of these fungal genera are known as opportunistic pathogens that led to respiratory diseases such as allergic rhinits. This study shows the importance of regular control of mycological contamination on water at DUs.
\end{abstract}

Key words: dental unit waterlines, dental equipments, filamentous fungi, mycological contamination, yeast.

\section{Introduction}

Water used in dental practices for activities such as oral rinsing and the cooling of dental equipment is generally supplied from the municipal water system. Dental unit waterlines (DUWLs), however, provide a suitable environment for microbial multiplication and the formation of biofilm which may be comprised of bacteria, fungi, and protozoa. A high number of microorganisms have been found in DUWLs (Walker et al., 2004; Göksay et al., 2008; Dogruöz et al., 2012). Although most microorganisms are harmless, potential pathogens such as Legionella, Pseudomonas, and Candida also have been detected (Walker et al., 2004; Türetgen et al., 2009). These microorganisms are of particular concern because of their ability to cause pneumonia, and other respiratory infections while wound infections are immunocompromised. Consequently, the quality of dental unit (DU) water is extremely important both for patients and dentists.

There have been many studies concerning the high levels of bacterial contamination, but little is known about fungal contamination in DUWLs (Williams et al., 1993; Barbeau et al., 1996; Genc et al., 1997; Walker et al., 2000; Walker et al., 2004; Szymanska, 2005a; Göksay et al., 2008; Türetgen et al., 2009). Candida spp. which can cause both superficial and systemic diseases have been recovered occasionally from DUWLs (Genc et al., 1997; Walker et al., 2004; Szymanska, 2005a). The fungi isolated from DUs water contained several yeasts, but mostly filamentous fungi (Pankhurst et al., 1998; Araujo and Contreras, 2004; Pitt, 2000; Walker et al., 2004; Szymanska, 2005a; Göksay et al., 2008). Aspergillus and Penicillium are the prevalent genera which have been isolated in DUWLs. It is known that, the spores of these genus members can cause allergic

Send correspondence to D.G. Kadaifciler. Department of Biology, Faculty of Science, Istanbul University, 34134 Vezneciler, Istanbul, Turkey. E-mail: duygugoksay@yahoo.com. 
reactions, asthma, and other respiratory problems. The research has suggested that fungal spores and hyphal fragments may be aerosolized into the air when contaminated water passes through dental equipments. In addition, several filamentous fungi are also potential toxin producers, and exposure to small amounts of toxins over several years may have negative effects on the immune system (Szymanska, 2005a). Owing to the hazardous effects of these microorganisms, we wanted to investigate the distribution of fungi in 41 DUWLs in 21 private and 20 public dental clinics. The aims of this study, then, were to determine the number and composition of the colonized mycobiota in the water from 41 DUWLs.

\section{Materials and Methods}

\section{Water sampling}

123 water samples were randomly collected from 41 DUs in the city of Istanbul, Turkey. 21 DUs were selected from different Private dental Clinics, whereas the other 20 DUs were at the same Public hospital's dental Clinics. 32 of the DUWLs were supplied with municipal water (containing chlorine), two DUWLs with distilled water, and seven DUWLs with commercial bottled water in polycarbonate containers. Water samples $(250 \mathrm{~mL})$ were taken from air-water syringes, high-speed drills, and inlet waters in the morning before patients arrived for treatment (Veronesi et al., 2007). Water temperature, $\mathrm{pH}$, and free chlorine values were measured.

\section{Mycological analysis}

For yeast definition, $100 \mu \mathrm{L}$ diluted samples $\left(10^{0}-10^{-2}\right)$ were spread-plated in triplicate onto Sabouraud Dextrose Agar (SDA) plates with streptomycin, and incubated at $30{ }^{\circ} \mathrm{C}$ for $48-72$ hours (Walker et al., 2000). After incubation, the yeast colonies were counted and were subcultured on SDA to identify colonies.

In order to determinate the filamentous fungi, $100 \mu \mathrm{L}$ diluted samples $\left(10^{0}-10^{-2}\right)$ were spread-plated in triplicate onto SDA with streptomycin, and incubated at $25{ }^{\circ} \mathrm{C}$ for 7 10 days (Pereira et al., 2009). After incubation, the colonies were counted and were subcultured on Potato Dextrose Agar to identify colonies.

\section{Enumeration and identification of yeast and filamentous fungi}

The quantities of yeast and filamentous fungi in each original sample were calculated using colony forming units per milliliter (cfu/mL). Gram staining, germ-tube formation and biochemical tests, including carbohydrate assimilation (API 20C AUX system) were applied for yeast identification (Arvanitidou et al., 1999).

Filamentous fungi were inoculated into various media (Czapek Yeast Autolysate Agar, Czapek Dox Agar, Czapek Yeast Autolysate Agar with 20\% Sucrose, 25\%
Glycerol Nitrate Agar, Malt Extract Agar, and Potato Dextrose Agar) and then identified as to genus and species level by microscophic and macroscophic methods according to generally accepted standards (Ellis, 1971; Klich, 2002; Porteus et al., 2003).

\section{Statistical analysis}

The mean of aerobic mesophilic fungi (AMF) counts and standard deviations were calculated. The MannWhitney U test was employed to detect statistically significant changes in the mean AMF of each water point (air- water syringes, high- speed drills, inlet waters). Statistical analysis were carried out using Spearman's Correlation Coefficient Test (SPSS, version 11, 5: SPSS Inc, Chicago, IL, USA) to examine the relationship between AMF counts at the different water points and $\mathrm{pH}$, free chlorine and temperature. Significant differences are reported at the $p<0.01$ level.

\section{Results and Discussion}

Studies conducted during the early years of microbial contamination in DUWLs focused mainly on bacterial colonization (Blake, 1963; Fitzgibbon et al., 1984; Furuhashi and Miyamae, 1985; Martin, 1987), in which the importance of fungal colonization was not completely understood. Although the presence of fungi in DU water has not been shown to present a demonstrable health risk either to patients or dentists. The existence of opportunistic pathogens in DU water is not consistent with accepted infection control principles. Although there are suggested standards for the bacterial control of DU waters and provision of unit' hygiene, no internationally recommended standard concerning fungi has yet been put forward (Anonymous, 1996; CDC, 2003). To the best of our knowledge, this is the first study reporting on mycological contamination in DUWLs in Istanbul, Turkey.

In this study, the number of AMF in the collected water samples ranged from $10-130 \mathrm{cfu} / \mathrm{mL}$ in outlet water from air-water syringes, $10-813 \mathrm{cfu} / \mathrm{mL}$ in outlet water from high speed drills and $10-160 \mathrm{cfu} / \mathrm{mL}$ in the water from units' inlet waters. The mean of AMF counts in air-water syringes, high-speed drills, and inlet waters were $36 \mathrm{cfu} / \mathrm{mL}, 101 \mathrm{cfu} / \mathrm{mL}$ and $45 \mathrm{cfu} / \mathrm{mL}$ respectively. A previous study conducted on 25 DUs reported the mean counts of fungi in reservoirs and, high-speed hand-pieces were $410 \mathrm{cfu} / \mathrm{mL}$ and $578 \mathrm{cfu} / \mathrm{mL}$. Researcher have generally preferred to use Malt Extract Agar as a medium (Szymans$\mathrm{ka}, 2006$ ), but as there is no internationally accepted standardized method for the isolation and determination of fungi in water environments various medias have been used in previous studies (Hageskal et al., 2006), which is why fungi counts may differ. Consequently, an internationally accepted standardized method for the isolation of fungi in water is necessary. 
The mean of the AMF counts was higher in highspeed drills than in air-water syringes. The Mann-Whitney $\mathrm{U}$ analysis revealed that there was a difference in the mean of the SDA plate counts obtained from air-water syringes and high-speed drills $(\mathrm{p}<0.01)$. We did not detect any significant difference between the mean of the AMF counts in the air-water syringes and inlet waters. The mean of the AMF counts was significantly higher in high-speed drills than inlet waters. The Mann-Whitney $U$ analysis revealed that there was a difference in the mean of the SDA plate counts obtained from high-speed drills and inlet water $(p<0.001)$. We also found that there was a difference between the mean counts of AMF in high-speed drills' outlet water and inlet waters $(p<0.001)$, suggesting microbial accumulation shows the formation of biofilm. Although some fungal genus was established in inlet water and different outlet points of DUWLs, some was determined only in the outlets of DUWLs (Table 1). This would suppose that these fungi entered and attached themselves into the system earlier and were then absorbed into the biofilm, which may protect fungi from disinfection. Biofilm also acts as conidia reservoirs. Biofilm breaks into fragments, and subsequently these may be released into the water flow interruptedly. As a result, contamination spreads throughout water systems (Hageskal et al., 2006). To remove biofilm and reduce the microbial counts are required daily or weekly continuous treatment of peroxide based disinfectant such as sterilex ultra, oxigenal, sanosil in DUWS (Walker et al., 2003).

Table 1 - The number of fungal species isolated in samples of water from air-water syringes, high-speed drills, and inlet water.

\begin{tabular}{|c|c|c|c|c|c|}
\hline $\begin{array}{l}\text { Dental unit } \\
\text { (code) }\end{array}$ & $\begin{array}{c}\text { Source of dental } \\
\text { unit }\end{array}$ & Names of isolated fungi & $\begin{array}{l}\text { A-W Syringe } \\
(\mathrm{cfu} / \mathrm{mL})\end{array}$ & $\begin{array}{r}\text { H-S Drill } \\
(\mathrm{cfu} / \mathrm{mL})\end{array}$ & $\begin{array}{c}\mathrm{IW} \\
\text { (cfu/mL) }\end{array}$ \\
\hline 1 & $\mathrm{P}$ & Cryptococcus laurentii (Kuff.) C.E. Skinner & $10 \pm 0$ & $17 \pm 3$ & 0.0 \\
\hline 2 & $\mathrm{P}$ & Filamentous fungi or yeast & 0.0 & 0.0 & 0.0 \\
\hline 3 & $\mathrm{P}$ & Penicillium waksmanii K.M. Zalessky & 0.0 & 0.0 & $10 \pm 0$ \\
\hline 4 & $\mathrm{P}$ & Penicillium waksmanii K.M. Zalessky & 0.0 & $27 \pm 6$ & 0.0 \\
\hline 5 & $\mathrm{P}$ & Candida famata E.K. Novák \& Zsolt & 0.0 & $47 \pm 19$ & 0.0 \\
\hline \multirow[t]{2}{*}{6} & $\mathrm{P}$ & Penicillium waksmanii K.M. Zalessky & $25 \pm 7$ & 0.0 & 0.0 \\
\hline & & Candida guilliermondii Castell. Langeron \& Guerra & 0.0 & $17 \pm 0$ & 0.0 \\
\hline 7 & $\mathrm{P}$ & Penicillium verrucosum Dierckx & 0.0 & $67 \pm 8$ & 0.0 \\
\hline 8 & $\mathrm{P}$ & Cladosporium sp. Link ex Fries & 0.0 & 0.0 & $73 \pm 15$ \\
\hline 9 & $\mathrm{P}$ & Cladosporium sp. Link ex Fries & $15 \pm 4$ & 0.0 & $160 \pm 17$ \\
\hline \multirow[t]{2}{*}{10} & $\mathrm{P}$ & Penicillium sp. Link ex Gray & 0.0 & $20 \pm 0$ & $20 \pm 10$ \\
\hline & & Penicillium verrucosum Dierckx & $45 \pm 10$ & 0.0 & 0.0 \\
\hline 11 & $\mathrm{P}$ & Candida famata E.K. Novák \& Zsolt & 0.0 & $20 \pm 5$ & $10 \pm 0$ \\
\hline 12 & $\mathrm{P}$ & Cryptococcus laurentii (Kuff.) C.E. Skinner & 0.0 & $67 \pm 21$ & $20 \pm 0$ \\
\hline 13 & $\mathrm{P}$ & Filamentous fungi or yeast & 0.0 & 0.0 & 0.0 \\
\hline 14 & $\mathrm{P}$ & Filamentous fungi or yeast & 0.0 & 0.0 & 0.0 \\
\hline 15 & $\mathrm{P}$ & Cladosporium sp. Link ex Fries & 0.0 & $16 \pm 1$ & 0.0 \\
\hline 16 & $\mathrm{P}$ & Filamentous fungi or yeast & 0.0 & 0.0 & 0.0 \\
\hline 17 & $\mathrm{P}$ & Cryptococcus laurentii (Kuff.) C.E. Skinner & $27 \pm 5$ & 0.0 & 0.0 \\
\hline 18 & $\mathrm{P}$ & Filamentous fungi or yeast & 0.0 & 0.0 & 0.0 \\
\hline 19 & $\mathrm{P}$ & Filamentous fungi or yeast & 0.0 & 0.0 & 0.0 \\
\hline 20 & $\mathrm{P}$ & Filamentous fungi or yeast & 0.0 & 0.0 & 0.0 \\
\hline 21 & PB & Non-sporulating fungi & $25 \pm 7$ & $130 \pm 0$ & 0.0 \\
\hline 22 & $\mathrm{~PB}$ & Filamentous fungi or yeast & 0.0 & 0.0 & 0.0 \\
\hline 23 & $\mathrm{~PB}$ & Non-sporulating fungi & $30 \pm 0$ & 0.0 & 0.0 \\
\hline 24 & $\mathrm{~PB}$ & Filamentous fungi or yeast & 0.0 & 0.0 & 0.0 \\
\hline 25 & $\mathrm{~PB}$ & Non-sporulating fungi & 0.0 & $200 \pm 53$ & 0.0 \\
\hline 26 & $\mathrm{~PB}$ & Filamentous fungi or yeast & 0.0 & 0.0 & 0.0 \\
\hline \multirow[t]{2}{*}{27} & $\mathrm{~PB}$ & Acremonium sp. Link ex Fries & $130 \pm 17$ & 0.0 & 0.0 \\
\hline & & Non-sporulating fungi & 0.0 & $13 \pm 2$ & 0.0 \\
\hline 28 & PB & Non-sporulating fungi & 0.0 & $500 \pm 46$ & 0.0 \\
\hline 29 & $\mathrm{~PB}$ & Non-sporulating fungi & 0.0 & $13 \pm 6$ & 0.0 \\
\hline 30 & $\mathrm{~PB}$ & Cladosporium sp. Link ex Fries & 0.0 & $100 \pm 17$ & 0.0 \\
\hline
\end{tabular}


Table 1 (cont.)

\begin{tabular}{|c|c|c|c|c|c|}
\hline $\begin{array}{l}\text { Dental unit } \\
\text { (code) }\end{array}$ & $\begin{array}{c}\text { Source of dental } \\
\text { unit }\end{array}$ & Names of isolated fungi & $\begin{array}{l}\text { A-W Syringe } \\
(\mathrm{cfu} / \mathrm{mL})\end{array}$ & $\begin{array}{r}\text { H-S Drill } \\
(\mathrm{cfu} / \mathrm{mL})\end{array}$ & $\begin{array}{c}\mathrm{IW} \\
\text { (cfu/mL) }\end{array}$ \\
\hline \multirow[t]{2}{*}{31} & \multirow[t]{2}{*}{$\mathrm{PB}$} & Aspergillus pseudoglaucus Blochwitz & 0.0 & $10 \pm 0$ & 0.0 \\
\hline & & Non-sporulating fungi & $130 \pm 14$ & $65 \pm 7$ & 0.0 \\
\hline 32 & $\mathrm{~PB}$ & Cladosporium sp. Link ex Fries & 0.0 & $813 \pm 40$ & 0.0 \\
\hline 33 & PB & Cladosporium sp. Link ex Fries & $20 \pm 0$ & $10 \pm 0$ & 0.0 \\
\hline 34 & PB & Non-sporulating fungi & 0.0 & $207 \pm 15$ & 0.0 \\
\hline 35 & PB & Penicillium decumbens Thom & 0.0 & $45 \pm 21$ & 0.0 \\
\hline 36 & $\mathrm{~PB}$ & Non-sporulating fungi & 0.0 & $40 \pm 14$ & 0.0 \\
\hline \multirow[t]{3}{*}{37} & \multirow[t]{3}{*}{$\mathrm{PB}$} & Non-sporulating fungi & 0.0 & $45 \pm 7$ & 0.0 \\
\hline & & Cladosporium sp. Link ex Fries & $10 \pm 0$ & 0.0 & 0.0 \\
\hline & & Penicillium sp. Link ex Gray & $10 \pm 0$ & 0.0 & 0.0 \\
\hline 38 & $\mathrm{~PB}$ & Non-sporulating fungi & 0.0 & $20 \pm 3$ & 0.0 \\
\hline \multirow[t]{2}{*}{39} & \multirow[t]{2}{*}{$\mathrm{PB}$} & Penicillium waksmanii K.M. Zalessky & $10 \pm 0$ & 0.0 & 0.0 \\
\hline & & Cladosporium sp. Link ex Fries & $10 \pm 0$ & 0.0 & 0.0 \\
\hline 40 & $\mathrm{~PB}$ & Filamentous fungi or yeast & 0.0 & 0.0 & 0.0 \\
\hline 41 & PB & Non-sporulating fungi & 0.0 & $27 \pm 6$ & 0.0 \\
\hline
\end{tabular}

A-W Syringe: Air-Water Syringe H-S Drill: High-Speed Drill IW: Inlet Water cfu/mL: Colony Forming Units per Mililitre P: Private dental clinic PB: Public dental clinic \pm : Standard Deviation.

Because of the negative effects of fungi on public health, we believe that further research, especially research associated with fungal biofilms in DUWLs, is required.

We investigated the temperature, $\mathrm{pH}$, and free chlorine of DU' influence on the fungal load of its water. And so the physical and chemical characteristics of DUs' outlet water were investigated. Water temperatures varied between $15-24{ }^{\circ} \mathrm{C}$. The $\mathrm{pH}$ values of outlet waters varied between 6.8-7.71. In the supply waters of two DUs' low levels of free chlorine were detected $(0.3$ and $0.5 \mathrm{ppm})$. Even if these conditions are suitable for AMF growth, it was found that there was no correlation between the AMF counts at the different water points and water temperature, $\mathrm{pH}$, and free chlorine, according to Spearman's correlation coefficient test.

The analysis of the water samples from the air-water syringes, detected fungi in 13 out of 41 DUs $(31.70 \%)$. Fungi isolated from these samples were identified as Cryptococcus laurentii, Penicillium waksmanii, Cladosporium spp., Penicillium verrucosum, Acremonium sp., and Penicillium $s p$. In the water flowing from high- speed drills, fungi were found in 23 out of 41 DUs $(56.09 \%)$. These identified fungi were: Cryptococcus laurentii, Penicillium waksmanii, Candida famata, Candida guilliermondii, Penicillium verrucosum, Cladosporium spp., Aspergillus pseudoglaucus, Penicillium decumbens, and Penicillium $s p$. The water samples from DUs' inlet waters revealed the presence of fungi in 6 out of 41 DUs (14.63\%). The fungi were identified as: Penicillium waksmanii, Cladosporium spp., Penicillium sp., Candida famata, and Cryptococcus laurentii. Non- sporulating fungi were found in $(29.26 \%)$ 12 out of 41 DUs (Table 1 ).
Water contaminated with yeast can be a risk if there is direct contact with open wounds. Many researches have found the species Candida in DUWLs (Genc et al., 1997; Walker et al., 2000; Araujo and Contreras, 2004; Szymanska, 2005b). Opportunistic pathogen yeast in the genus Candida can cause skin and systemic disease. While Candida albicans is generally considered to be the most pathogenic of the Candida species, a variety of other members of this genus have been cited as the causative agents of an increasing number of infections (Szymanska, 2005b). In this study, Candida guilliermondii, Candida famata, and Cryptococcus laurentii were isolated from the different water points of DUs. Aerosols originating from DU water below $2.5 \mu \mathrm{m}$ are considered dangerous. These small aerosols which contain microorganisms can induce asthma, rhinitis, allergic alveolitis, or other respiratory problems (Gorny, 2004). In previous studies on DU water, Fusarium, Cladosporium, Alternaria, Aspergillus, Penicillium, and Scopulariopsis have been determined (Szymanska, 2005a; Göksay et al., 2008). Aspergillus and Penicillium are the most common genera of those found in aquatic environmental studies. There spores are known to cause allergic reactions (Asan et al., 2003; Asan, 2004). Moreover Cladosporium and Alternaria are known to provoke respiratory and asthmatic symptoms in immunocompromised people. From our study, isolated fungi such as Aspergillus, Penicillium, and Cladosporium spp. could also create these harmful effects. To our knowledge, the potential allergic and infectious characteristics of fungi have not been studied in municipal water systems such as in DUWLs. Hence there is no detailed information about fungal infections in 
the human population. Epidemiological researches, therefore, needs to be conducted in the future.

\section{Acknowledgments}

We appreciate Prof. Dr. Ahmet ASAN for fruitful discussions during the preparation of this paper.

\section{References}

Anonymous (1996) American Dental Association statement on dental unit waterlines. J Am Dent Assoc 127:185-186.

Araujo R, Contreras N (2004) Microbiological contamination of dental unit water systems in general practices from Barcelona (Spain). Water Sci Technol 4:1-5.

Arvanitidou M, Kanellou K, Constantinides TC, Katsouyannopoulos V (1999) The occurence of fungi in hospital and community potable waters. Lett Appl Microbiol 29:81-84.

Asan A (2004) Aspergillus, Penicillium and related species reported from Turkey. Mycotaxon 89:155-157.

Asan A, Kirgiz T, Sen B, Camur-Elipek B, Guner U, Guher H (2003) Isolation, identification and seasonal distribution of airborne and waterborne fungi in Terkos lake (IstanbulTurkey). J Basic Microbiol 43:83-95.

Barbeau J, Tanguay R, Faucher E, Avezard C, Trudel L, Cote L, Prevost AP (1996) Multiparametric analysis of waterline contamination in dental units. Appl Environ Microbiol 62:3954-3959.

Blake GC (1963) The incidence and control of bacterial infection in dental spray reservoirs. Brit Dent J 115:413-416.

Centers for Disease Control (CDC) and Prevention: Guidelines for infection control in dental health -care settings. (2003) MMWR Report 52:1-66.

Doggett MS (2000) Characterization of fungal biofilms within a municipal water distribution system. Appl Environ Microbiol 66:1249-1251.

Dogruöz N, Ilhan-Sungur E, Göksay D, Türetgen I (2012) Evaluation of microbial contamination and distrubition of sulphate reducing bacteria in dental units. Environ Monit Assess 184:133-139.

Ellis MB (1971) Dematiaceous Hyphomycetes. The Eastern Press Ltd., London and Reading, Commonwealth Mycological Institute, U.K.

Fitzgibbon EJ, Bartzokas CA, Martin MV, Graham R (1984) The source, frequency and extent of bacterial contamination of dental unit water systems. Brit Dent J 157:98-101.

Furuhashi M, Miyamae T (1985) Prevention of bacterial contamination of water in dental units. J Hosp Infect 6:81-88.

Genc A, Kadir T, Ercalik S, Erdem H, Demirbas B (1997) The probability of microbial contamination by the internal water/air lines of turbines. Turkish Dental Association IV International Dental Congress, Istanbul, TR, pp 131.

Gorny RF (2004) Filamentous microorganisms and their fragments in indoor air- a review. Ann Agric Environ Med 11:185-197.

Göksay D, Çotuk A, Zeybek Z (2008) Microbial contamination of dental unit waterlines in Istanbul, Turkey. Environ Monit Assess 147:265-269.
Hageskal G, Knutsen AK, Gaustad P, De Hooh GS, Skaar I (2006) Diversity and significance of mold species in Norwegian drinking water. Appl Environ Microbiol 72:7586-7593.

Hageskal G, Lima N, Skaar I (2009) The study of fungi in drinking water. Mycol Res 113:165-172.

Klich MA (2002) Identification of common Aspergillus Species. Centraalbureau voor Schimmelcultures Press, Utrecht, Netherlands.

Martin MV (1987) The significance of the bacterial contamination of dental unit water systems. Brit Dent J 163:152-154.

Pankhurst CL, Johnson NW, Woods RG (1998) Microbial contamination of dental unit waterlines: the scientific argument. Int Dent J 48:359-368.

Pereira VJ, Basilio MC, Fernandes D, Domingues M, Paiva JM, Benoliel MJ, Crespo MT, San Romao MV (2009) Occurence of filamentous fungi and yeasts in three different drinking water sources. Water Res 43:3813-3819.

Pitt JI (2000) A laboratory guide to common Penicillium species. Australia Food Science Australia Press, North Ryde, New South Wales, Australia.

Porteus NB, Grooters AM, Redding SW, Thompson EH, Rinaldi MG, De Hoog GS, Sutton DA (2003) Identification of Exophiala mesophila isolated from treated dental unit waterlines. J Clin Microbiol 41:3885-3889.

Szymanska J (2005a) Evaluation of mycological contamination of dental unit waterlines. Ann Agric Environ Med 12:153-155.

Szymanska J (2005b) Microbiological risk factors in dentistry. Current status of knowledge. Ann Agric Environ Med 12:157-163.

Szymanska J (2006) Antifungal efficacy of hydrogen peroxide in dental unit waterline disinfection. Ann Agric Environ Med 13:313-317.

Türetgen I, Göksay D, Cotuk A (2009) Comparison of the microbial load of incoming and distal outlet waters from dental unit water systems in Istanbul. Environ Monit Assess 158:9-14.

Veronesi L, Capobianco E, Affanni P, Pizzi S, Vitali P, Tanzi ML (2007) Legionella contamination in the water system of hospital dental settings. Acta Biomed 78:117-122.

Walker JT, Bradshaw DJ, Bennett AM, Fulford MR, Martin MV, Marsh PD (2000) Microbial biofilm formation and contamination of dental-unit water systems in general dental practice. Appl Environ Microbiol 66:3363-3367.

Walker JT, Bradshaw DJ, Finney M, Fulford MR, Frandsen E, Qstergaard E, Ten Cate JM, Moorer WR, Schel AJ, Mavridou A, Kamma JJ, Mandilara G, Stösser L, Kneist S, Araujo R, Contreras N, Goroncy-Bermes P, Q'Mullane D, Burke F, Forde A, Q'Sullivan M, Marsh PD (2004) Microbiological evaluation of dental unit water systems in general dental practice in Europe. Eur J Oral Sci 112:412-418.

Walker JT, Bradshaw DJ, Fulford MR, Marsh PD (2003) Microbiological evaluation of a range of disinfectant products to conrol mixed-species biofilm contamination in a laboratory model of a dental unit water system. Appl Environ Microbiol 69:3327-3332.

Williams JF, Johnston AM, Johnston B, Hungtington MK, Mackenzie CD (1993) Microbial contamination of dental unit waterlines: prevalence, intensity and microbiological characteristics. J Am Dent Assoc 124:59-65.

All the content of the journal, except where otherwise noted, is licensed under a Creative Commons License CC BY-NC. 